\title{
Strategi Komunikasi Studi Analisis QS Al-Alaq
}

\section{Khurotin Anggraeni}

\section{Lecture of Faculty Da'wah and Islamic Communication}

Institute for Islamic Studies (IAI) Pangeran Diponegoro Nganjuk East Java Republic

\section{Indonesia}

Email: khurotin_anggraeni@iaipd-nganjuk.ac.id

\begin{abstract}
ABSTRAK
Perkembangan komunikasi yang menjadikan banyak bentuk kajian terhadap komunikasi yang bertujuan untuk bagaimana agar pesan tersebut sampai pada penerima pesan. bentuk analisa $\mathrm{Al}$ Qur'an Surat Al-Alaq dimana surat ini sebenarnya digunakan sebagai rujukan kajian pendidikan tetapi setelah melihat struktur bahasa dalam ayat-ayat Qs Al-Alaq merupakan kolaborasi sebuah komunikasi yang tersirat antara Allah dan Rosulullah ketika menerima wahyu pertama. penulis tidak mengkaji dalam bentuk per-ayat tetapi dalam bentuk analisa surat, karena penulis beranggapan bahwa tidaklah mungkin suatu ayat yang disatukan menjadi suatu surat tanpa terdapat suatu hal ingin ditunjukkan dalam surat tersebut. Bentuk komunikasi ini nantinya digunakan dalam komunikasi penyiaran Islam, penyampaian pesan yang digunakan sebagai proses pengambilan keputusan bersama untuk membentuk perubahan sosial yang memiliki fungsi menyebarluaskan pesan komunikasi yang menjembatani culture gab. komunikasi yang menekankan pada keberhasilan meraih khalayak sebanyak mungkin, meningkatkan kesadaran dan mengarahkan perilaku. dengan menganalisa nilai-nilai membina dan memotivasi agar dapat mencapai tujuan yang diinginkan komunikator. Didalam strategi komunikasi antara Allah dan Rosullnya dapat dianalisis kedalam empat bagian diantaranya tahapan pertama adalah memberikan pengetahuan terlebih dahulu yang sesuai dengan experiencenya dengan media kalam, tahapan yang kedua adalah mengajak berdialog, tahapan yang ketiga adalah memberi pemahaman dan tahapan yang terakhir adalah memberikan peringatan.
\end{abstract}


$\int \begin{aligned} & \text { p-ISSN: } 2723-4703 \\ & \text { e-ISSN: - } \\ & \text { http://ejurnal.iaipd-nganjuk.ac.id/index.php/j-kis/ } \\ & \text { KURNALUNIKASI ISLAM }\end{aligned}$

Kata Kunci: Strategi, Komunikasi, Qs Al Alaq

\section{PENDAHULUAN}

Perkembangan komunikasi begitu cepat dan pesat, dapat dilihat dari berbagai macam cara manusia menyampaikan pesannya. Dengan melalui berbagai media, mulai dari visual (Majalah, Koran, ), audio (Radio), sampai ke oudio visual (televisi, HP), yang intinya hanya bagaimana agar pesan tersebut sampai pada penerima pesan. Dalam hal ini adalah masyarakat pada umumnya belum sampai pada bagaiman pesan tersebut lebih mengena kepada penerima pesan. Tidak hanya proses mengetahui saja tetapi harus sampai pada tahapan mengkaji, atau bahkan sampai melakukan analisis terhadap pesan tersebut dan bisa sampai mengikuti apa yang disampaikan pesan tersebut.

Dalam penyiaran Islam pesan tersebut harus sampai pada mengikuti apa yang dikatakan dalam pesan tersebut tidak hanya pada tahapan mengetahui saja. Proses ini lebih sulit dari pada hanya penyampaian pesan yang dikatagorikan dalam mengetahui saja, dibutuhkan suatu strategi -strategi yang bisa mewujutkan pesan tersebut mengenai kepada si penerima pesan. Al qur'an merupakan kitab yang diturunkan oleh Allah yang digunakan sebagai salah satu sarana untuk berkomunikasi dengan hambanya, komunikasi antara Allah dengan malaikat, dengan para nabi, dengan iblis, dengan manusia dengan perantara rosul. ${ }^{1}$ Maka dalam hal ini penulis ingin meneliti strategi -strategi komunikasi dalam Qs Al-Alaq Dimana surat ini sebenarnya digunakan sebagai rujukan kajian pendidikan tetapi setelah melihat struktur bahasa dalam ayat-ayat Qs Al-Alaq merupakan kolaborasi sebuah komunikasi yang tersirat antara Allah dan Rosulullah ketika menerima wahyu pertama.

Dari analisa ini mengapa penulis mengambil komunikasi yang tersirat antara Allah dan rosulnya, dan mengapa tidak mengambil komunikasi antara manusia dengan manusia? Dalam hal ini penulis mengambil komunikasi tersebut sebagai pembelajaran strategi komunikasi yang ada yang bisa digunakan dalam strategi komunikasi antara manusia

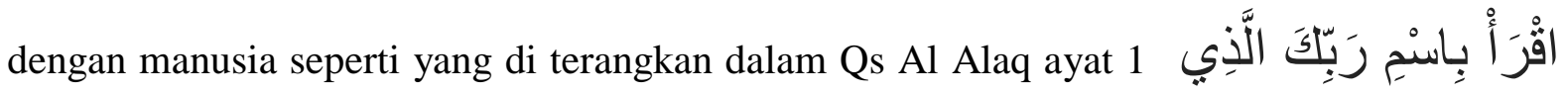
خَلَثْ yang berarti “bacalah” dari membaca keadaan tersebut bisa dipelajari dan dianalisi

\footnotetext{
${ }^{1}$ Harjani hefni, Komunikasi Islam (Jakarta: Kencana 2003)
} 


\section{$\int \begin{aligned} & \text { p-ISSN: } 2723-4703 \\ & \text { e-ISSN: }- \\ & \text { http://ejurnal.iaipd-nganjuk.ac.id/index.php/j-kis/ } \\ & \text { KURNAL }\end{aligned}$}

yang nantinya analisa ini digunakan dalam strategi komunikasi dalam berdakwah. Sebenarnya banyak ayat yang digunakan sebagai acuan komunikasi diantara:

Qs al khafi 110,

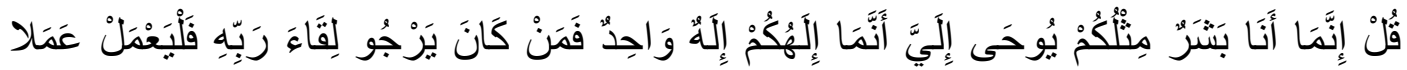

$$
\begin{aligned}
& \text { صَالِحًا وَلا يُشْرِ كَكْ بِعِبَادَةِ رَبِّهِ أَحَدًا }
\end{aligned}
$$

Katakanlah (Muhammad), "Sesungguhnya aku ini hanya seorang manusia seperti kamu, yang telah menerima wahyu, bahwa sesungguhnya Tuhan kamu itu adalah Tuhan Yang Maha Esa." Maka barang siapa mengharap pertemuan dengan Tuhannya, maka hendaklah dia mengerjakan amal yang salehdan janganlah dia mempersekutukan dengan sesuatu pun dalam beribadah kepada Tuhannya

Qs Al Ahzab 45-46,

\section{.}

Hai Nabi sesungguhnya kami mengutusmu untuk jadi saksi, dan pembawa kabar gembira dan pemberi peringatan,

\section{.}

dan untuk jadi penyeru kepada Agama Allah dengan izin-Nya dan untuk jadi cahaya yang menerangi.

Qs Asaba' 28,

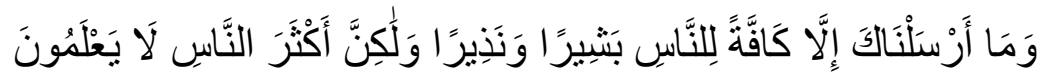

Dan Kami tidak mengutus kamu, melainkan kepada umat manusia seluruhnya sebagai pembawa berita gembira dan sebagai pemberi peringatan, tetapi kebanyakan manusia tiada mengetahui.

Tetapi penulis tidak mengkaji dalam bentuk per-ayat tetapi dalam bentuk analisa surat, karena penulis beranggapan bahwa tidaklah mungkin suatu ayat yang disatukan menjadi suatu surat tanpa terdapat suatu hal ingin ditunjukkan dalam surat tersebut, maka dari itu saya ingin lebih mengkaji dan mendalami Qs Al-alaq dalam kajian strategi komunikasi.

\section{KAJIAN PUSTAKA}

\section{Qs Al Alaq}




\section{$\int \begin{aligned} & \text { p-ISSN: 2723-4703 } \\ & \text { e-ISSN: - } \\ & \text { http://ejurnal.iaipd-nganjuk.ac.id/index.php/j-kis/ } \\ & \text { KOMUNALIKASI ISLAM }\end{aligned}$

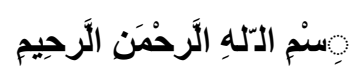

\section{Dengan nama Allah Yang Maha Penyayang dan Maha Pengasih.}

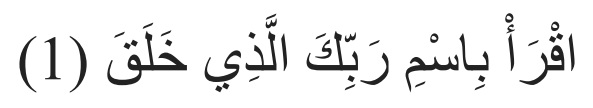

1. Bacalah dengan (menyebut) nama Tuhanmu yang Menciptakan,

$$
\text { خَلَقَ الْإِنْسَانَ مِنْ عَلَقٍِ (2) }
$$

2. Dia Telah menciptakan manusia dari segumpal darah.

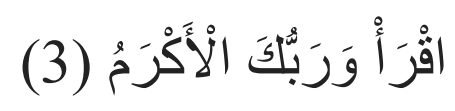

3. Bacalah, dan Tuhanmulah yang Maha pemurah,

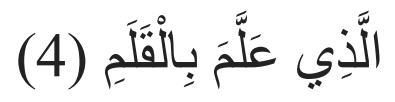

4. Yang mengajar (manusia) dengan perantaran kalam[*],

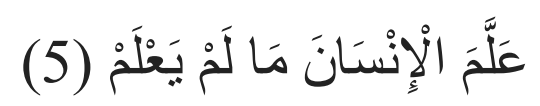

5. Dia mengajar kepada manusia apa yang tidak diketahuinya

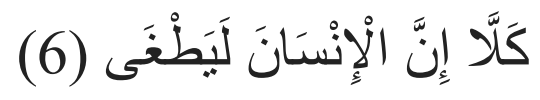

6. Ketahuilah! Sesungguhnya manusia benar-benar melampaui batas,

Diriwayatkan oleh 'Aisyah dalam sebuah hadist dalam kitab Shohih Bukhori: (HR Bukhori 6467) $^{2}$ yang di kuatkan dengan hadis lain diantaranya hadis no 3 dan 4572 dari dari hadist riwayat Bukhori.

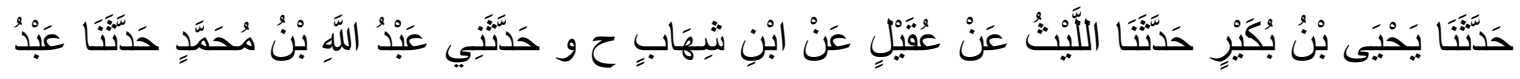

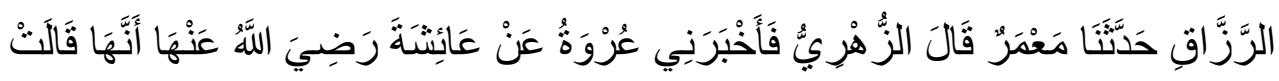

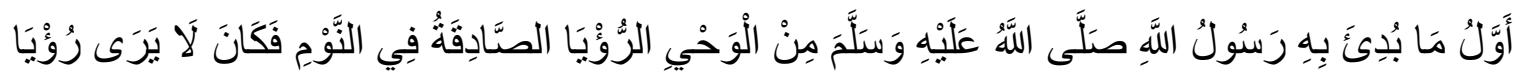

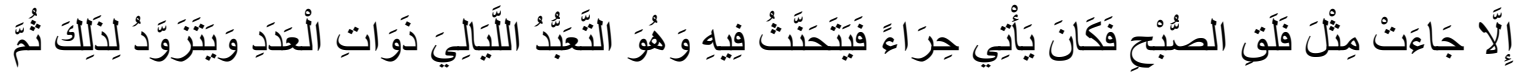

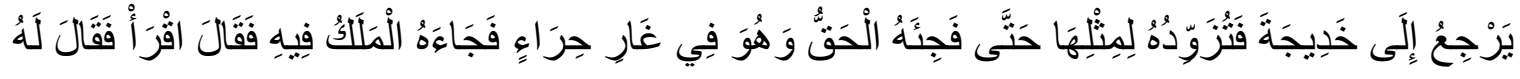

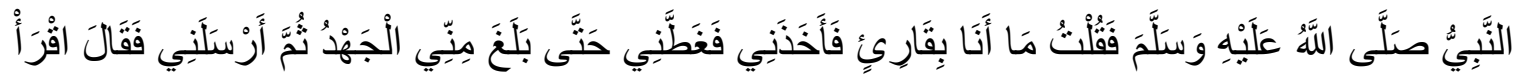

\footnotetext{
${ }^{2}$ Lidwa Pusaka i-Software - Kitab 9 Imam Hadist Sumber : Bukhari Kitab : Ta'bir Bab : Wahyu pertama-
} tama No. Hadist : 6467 


\section{$J-\mathbf{K} \mathbf{I}^{2} \mathbf{S}$}

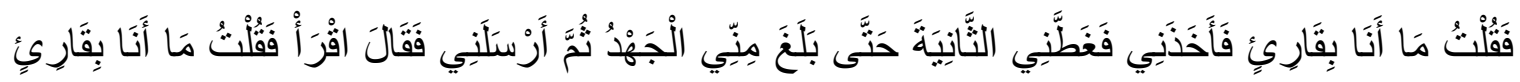

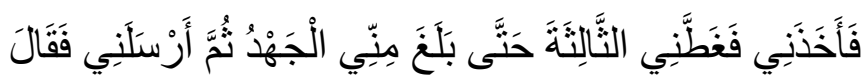

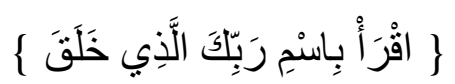

حَنَّى بَلَغَ خلَّن

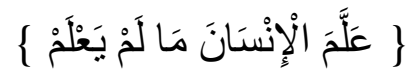

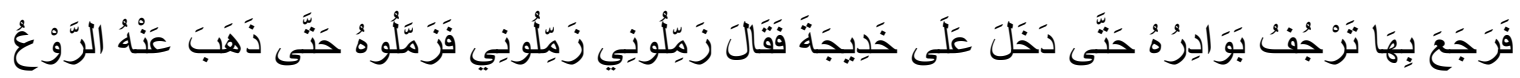

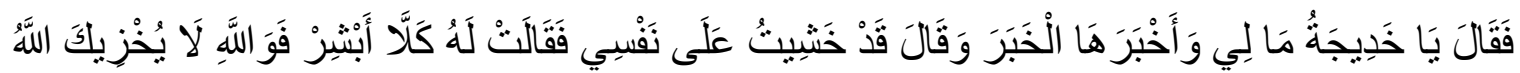

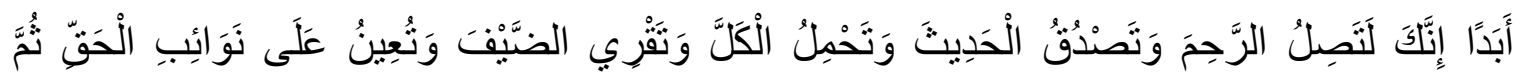

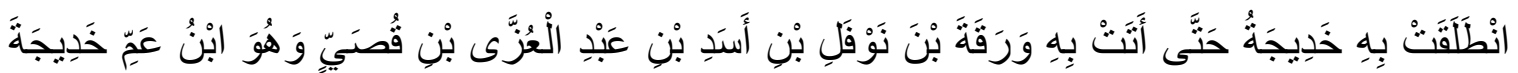

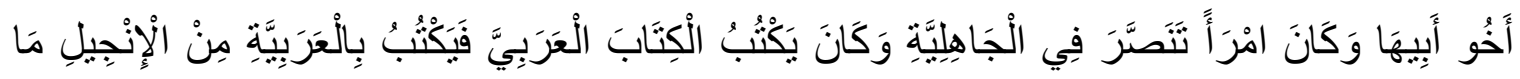

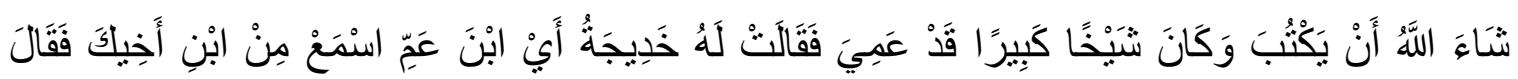

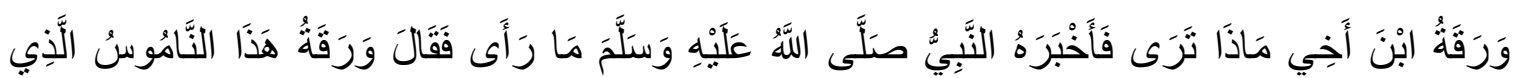

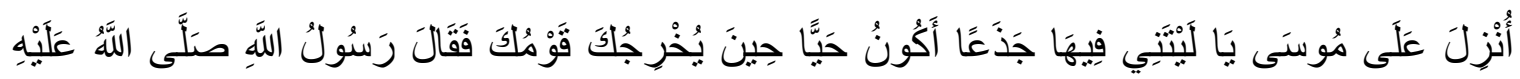

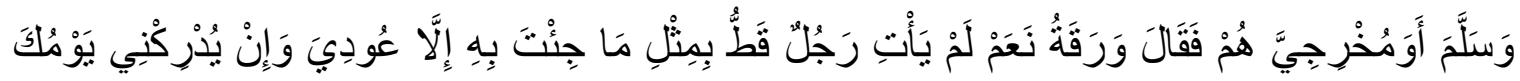

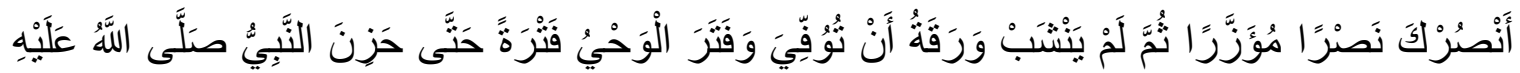

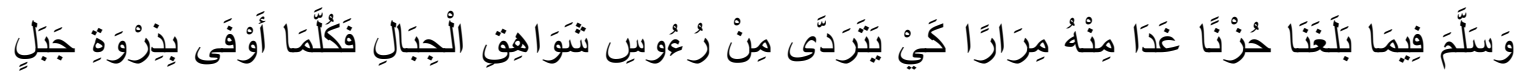

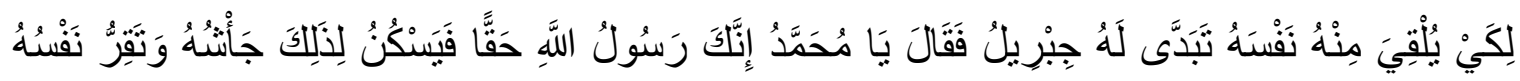

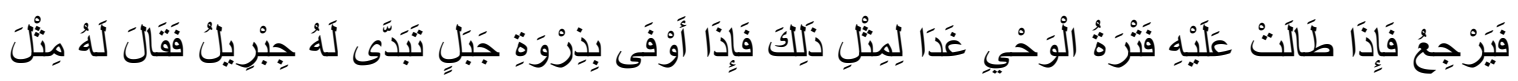
ذَلِلَد

قَالَ ابْنُ عَبَّاسِ

\{ فَالِقُ الْإصنْبَاح

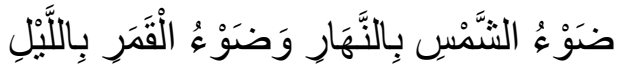

Telah menceritakan kepada kami Yahya bin Bukair telah menceritakan kepada kami Al Laits dari Uqail dari Ibnu Syihab -lewat jalur periwayatan lain-Dan Telah menceritakan kepadaku 'Abdullah bin Muhammad telah menceritakan kepada kami 'Abdurrazaq telah menceritakan kepada kami Ma'mar, Az Zuhri mengatakan, telah menceritakan kepadaku Urwah dari Aisyah radliallahu 'anha, ia menceritakan; wahyu pertama-tama yang diturunkan kepada Rasulullah 
$\int \begin{aligned} & \text { p-ISSN: } 2723-4703 \\ & \text { e-ISSN: - } \\ & \text { http://ejurnal.iaipd-nganjuk.ac.id/index.php/j-kis/ } \\ & \text { KURNAL }\end{aligned}$

Shallallahu'alaihiwasallam adalah berupa mimpi yang baik ketika tidur, beliau tidak bermimpi selain datang seperti fajar subuh, dan beliau selalu pergi ke goa Hira bertahannus di sana, yaitu beribadah beberapa malam, dan beliau untuk hal tersebut berbekal, kemudian kembali kepada Khadijah agar dia dapat membekali beliau untuk keperluan seperti itu, sampai akhirnya beliau di kejutkan dengan al haq ketika beliau sedang berada di dalam goa Hira', malaikat datang kepada beliau dan berujar; 'bacalah! ' Nabi shallallahu 'alaihi wasallam berkata kepadanya; "maka aku menjawab; 'Saya tidak bisa membaca! ' Lalu dia mendekapku dan menutupiku hingga aku kepayahan. kemudian melepasku dan berkata; 'Bacalah! ' aku menjawab; 'Saya tidak bisa membaca!' Ia mendekapku lagi dan menutupiku untuk kedua kalinya hingga aku kepayahan, kemudian melepasku lagi seraya mengatakan; 'Bacalah!' saya menjawab; 'Saya tidak bisa membaca.' Maka ia mendekapku dan menutupiku untuk kali ketiganya hingga aku kepayahan, kemudian melepasku lagi dan mengatakan; 'IQRO' BISMI ROBBIKAL LADZII KHOLAQO sampai ayat 'ALLAMAL INSAANA MAA LAM YA'LAM, '" kemudian beliau pulang dengan menggigil hingga menemui Khadijah dan berkata; "Selimutilah aku, selimutilah aku!" maka keluarganya pun menyelimuti beliau, sampai rasa ketakutan beliau menghilang, kemudian beliau berkata: "ya Khadijah, apa yang terjadi pada diriku?" beliau menceritakan peristiwa tersebut kepadanya dan berkata; "Aku mengkhawatirkan diriku" Maka Khadijah menjawab: 'Sekali-kali tidak, bergembiralah, demi Allah, Allah tidak akan menghinakanmu selama-lamanya, sebab engkau suka menyambung silaturrahim, berkata jujur, menghilangkan kesusahan serta menjamu tamu, serta membela kebenaran!' Maka Khadijah pergi bersama beliau menemui Waraqah bin naufal bin Asad bin Abdul Uzza bin Qushshay, anak paman Khadijah, atau saudara ayahnya, ia adalah semasa jahiliyah beragama nashrani dan suka menulis kitab suci arabi, ia menulis injil arabi dengan kehendak Allah, dan dia seorang kakek yang cukup umur dan buta. Maka Khadijah berkata kepadanya; 'Wahai anak paman, dengarlah (apa yang dituturkan) anak saudaramu! ' Waraqah bertanya; 'Hai anak saudaraku, apa yang telah kau lihat? ' Maka Nabi shallallahu 'alaihi wasallam mengabarkan apa yang telah beliau lihat, spontan Waraqah mengatakan; 'Ini adalah Namus yang pernah diturunkan kepada Musa, duhai sekiranya ketika itu aku masih gagah perkasa dan masih hidup, ketika kaummu mengusirmu! ' "Adakah kaumku akan mengusirku?" Tanya Nabi shallallahu 'alaihi wasallam. Waraqah menjawab; 'Iya, tidak ada seorang pun yang membawa seperti yang kau bawa, melainkan ia akan dimusuhi. Jikalau aku temui hari-harimu, niscaya aku membelamu dengan gigih.' kemudian tak berselang lama Waraqah meninggal dan wahyu berhenti beberapa lama hingga Nabi shallallahu 'alaihi wasallam sedih. Berita yang sampai kepada kami, kesedihan yang beliau alami sedemikian rupa, hingga beliau beberapa kali ingin 
bunuh diri dengan cara menerjukan diri dari puncak gunung, setiap kali beliau naik puncak gunung untuk menerjunkan dirinya, Jibril menampakkan diri dan mengatakan; 'hai Muhammad, sesungguhnya engkau betul-betul Rasulullah! ' nasehat ini menjadikan hatinya lega dan jiwannya tenang dan pulang. Namun jika sekian lama wahyu tidak turun, jiwanya kembali terguncang, dan setiap kali ia naik puncak gunung untuk bunuh diri, Jibril menampakkan diri dan menasehati semisalnya. Ibnu Abbas mengatakan tentang ayat; 'Faaliqul ishbah' yaitu cahaya matahari ketika siang, dan cahaya bulan ketika malam.

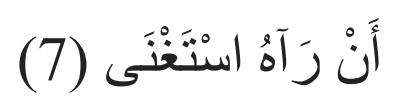

7. Karena dia melihat dirinya serba cukup.

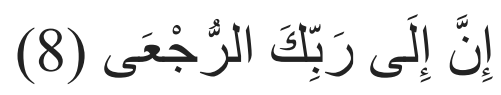

8. Sesungguhnya Hanya kepada Tuhanmulah kembali(mu).

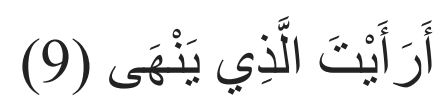

9. Bagaimana pendapatmu tentang orang yang melarang,

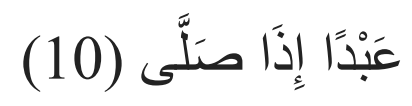

10. Seorang hamba ketika mengerjakan shalat [**],

$$
\text { أَرَأَيْتَتَ إِنْ كَانَ عَلَى الْهُدَى (11) }
$$

11. Bagaimana pendapatmu jika orang yang melarang itu berada di atas kebenaran,

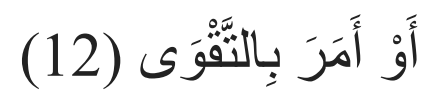

12. Atau dia menyuruh bertakwa (kepada Allah)?

$$
\text { أَرَأَبْْتَ إنْن كَذَّبَ وَنَوَلَّلَى (13) }
$$

13. Bagaimana pendapatmu jika orang yang melarang itu mendustakan dan berpaling?

$$
\text { أَلَمْ بَعْلَمْ بِأَنَّ اللَّهَ يَرَى (14) }
$$

14. Tidaklah dia mengetahui bahwa Sesungguhnya Allah melihat segala perbuatannya?

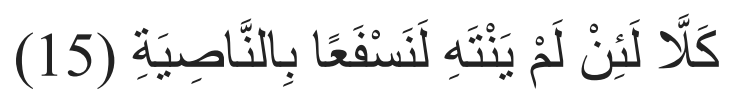




\section{$\int \begin{aligned} & \text { p-ISSN: } 2723-4703 \\ & \text { e-ISSN: - } \\ & \text { http://ejurnal.iaipd-nganjuk.ac.id/index.php/j-kis/ }\end{aligned}$}

15. Ketahuilah, sungguh jika dia tidak berhenti (berbuat demikian) niscaya kami tarik ubun-ubunnya [***]

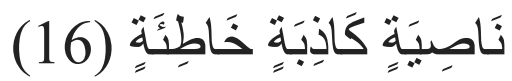

16. (yaitu) ubun-ubun orang yang mendustakan lagi durhaka.

$$
\text { فَلْبَدْعُ نَادِبَهُهُ (17) }
$$

17. Maka Biarlah dia memanggil golongannya (untuk menolongnya),

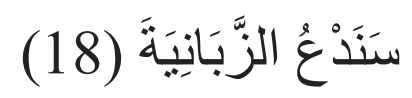

18. Kelak kami akan memanggil malaikat Zabaniyah [****],

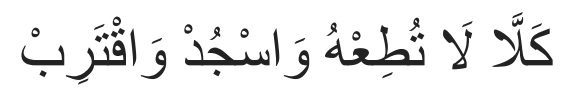

19. Sekali-kali jangan, janganlah kamu patuh kepadanya; dan sujudlah dan dekatkanlah (dirimu kepada Tuhan)

* Yang dimaksud dengan orang yang hendak melarang itu ialah Abu Jahal, yang dilarang itu ialah Rasulullah sendiri. akan tetapi usaha ini tidak berhasil karena Abu Jahal melihat sesuatu yang menakutkannya. setelah Rasulullah selesai shalat disampaikan orang berita itu kepada Rasulullah. kemudian Rasulullah mengatakan: "Kalau jadilah Abu Jahal berbuat demikian pasti Dia akan dibinasakan oleh Malaikat".

** Maksudnya: memasukkannya ke dalam neraka dengan menarik kepalanya.

***Malaikat Zabaniyah ialah Malaikat yang menyiksa orang-orang yang berdosa di dalam neraka.

Diriwayatkan oleh Ibnul Mundzir yang bersumber dari Abu Hurairah bahwa Abu Jahal pernah berkata, “Apakah Muhammad meletakkan mukanya ke tanah (sujud) di hadapan kamu ?" ketika itu orang membenarkannya. Selanjutnya Abu Jahal berkata: "Demi al-Lata dan al-'Uzza, sekiranya aku melihat dia sedang berbuat demikian, akan aku injak batang lehernya dan kubenamkan mukanya ke dalam tanah." Ayat-ayat ini (6-19) turun berkenaan dengan peristiwa tersebut.

Diriwayatkan oleh Ibnu Jarir yang bersumber dari Ibnu 'Abbas bahwa ketika Rasulullah saw sedang shalat, datanglah Abu Jahal melarang beliau melakukannya. Ayat- 


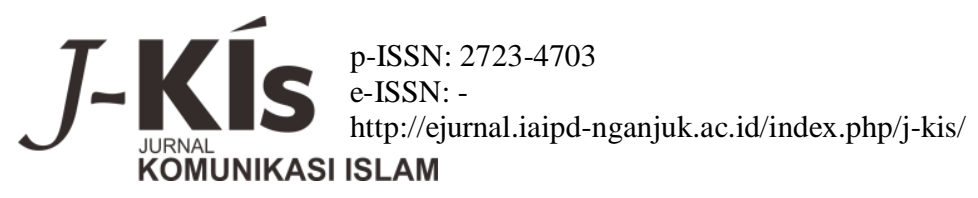

Volume 01, Nomor 01

Juni 2020

ayat 6-19 ini turun berkenaan dengan peristiwa tersebut sebagai ancaman kepada orang yang menghalang-halangi orang yang hendak beribadah.

Diriwayatkan oleh at-Tirmidzi dan lain-lain, yang bersumber dari Ibnu 'Abbas, menurut at-Tirmidzi hadits ini hasan shahih, bahwa ketika Rasulullah saw sedang shalat, datanglah Abu Jahal seraya berkata: "Bukankah aku sudah melarang engkau berbuat demikian (shalat) ?" Nabi Muhammad saw pun membentaknya. Abu Jahal berkata: "Bukankah engkau tau bahwa di sini tidak ada orang yang lebih banyak pengikutnya daripada aku ?” maka Allah menurunkan ayat-ayat ini (al-“Alaq 17-19) sebagai ancaman kepada orang yang menghalang-halangi orang yang hendak melakukan ibadah dan merasa banyak pengikut. $^{3}$

\section{Strategi Komunikasi}

\section{Pengertian Strategi}

Strategi menurut Purnomo Setiawan Hari sebenarnya berasal dari bahasa Yunani "strategos" diambil dari kata stratos yang berarti militer dan Ag yang berarti memimpin. Jadi strategi dalam konteks awalnya ini diartikan sebagai general ship yang artinya sesuatu yang dikerjakan oleh para jenderal dalam membuat rencana untuk menaklukkan musuh dan memenangkan perang. ${ }^{4}$ Strategi pada hakikatnya adalah perencanaan (planning) dan manajemen (management) untuk mencapai suatu tujuan.Tetapi untuk mencapai tujuan tersebut, strategi tidak berfungsi sebagai peta jalan yang hanya menunjukkan arah saja, melainkan harus menunjukan bagaimana taktik operasionalnya.

Definisi Strategi menurut siagian adalah serangkaian keputusan dan tindakan yang mendasar yang dibuat oleh manajemen puncak yang diterapkan keseluruh jajarannya dalam suatu organisasi demi pencapaian tujuan organisasi

\footnotetext{
${ }^{3}$ https://alquranmulia.wordpress.com/2013/01/05/asbabun-nuzul-surah-al-alaq/

${ }^{4}$ Setiawan Hari Purnomo, Manajemen Strategi : Sebuah Konsep Pengantar, (Jakarta:Fakultas Ekonomi Universitas Indonesia, 1996)8
} 
tersebut. ${ }^{5}$ Strategi digunakan untuk tujuan jangka panjang, strategi menciptakan suatu makna. Dalam makalah ini strategi dimaknai penciptaan suatu makna yang ada di dalam Qs Al Alaq yang mengkaji tidak hanya satu ayat melainkan surat yang mana tidak mungkin dalam surat tersebut yang disatukan berbagai ayat yang ada tidak mungkin terdapat makna yang diisaratkan, maka dari itu dalam kajian ini penulis mencoba untuk menyiratkan makna qs al alaq dari kajian komunikasi. Yang dibentuk dalam satu strategi menciptakan suatu makna.

2. Pengertian komunikasi

Komunikasi berasal dari bahasa latin yang berarti "Communis" atau dalam bahasa inggis yang berarti "commun" yang berarti umum atau sama. Apabila kita komunikasi ini berarti kita berada dalam keadaan berusaha untuk menimbulkan kesamaan. ${ }^{6}$

Banyak ahli yang yang mendefinisikan mengenai komunikasi dalam arti sempit komunikasi dimaknai sebagai "penyampaian pesan” kemudian dalam arti luas dapat dimaknai "komunikasi antara dua makluk". Menurut Roger menyatakan faktorfaktor komunikasi merupakan hal yang penting dalam banyak aspek proses pengambilan keputusan yang bersama- sama membentuk perubahan social. Dari banyaknya pengertian komunikasi dapat dipilah menjadi tiga bagian:

a. Komunikasi satu arah (linier)

Komunikasi adalah proses dimana pesan diibaratkan mengalir dari sumber dengan melalui beberapa komponen yang menuju kepada komunikan. Model komunikasi yang mula-mula di perkenalkan oleh Harol D. Lasswell yang menyatakan dengan tepat sebuah tindakan komunikasi dengan menjawab pertanyaan-pertanyaan "who, says what, which channel, to whom, whit what effect" kemudian dilanjutkan dengan model Shannon dan Weaver yang menyatakan Elemen pertama pada komunikasi adalah sumber informasi yang menghasilkan sebuah pesan atau rangkaian pesan

\footnotetext{
${ }^{5}$ Sondang P Siagian, Filsafah Administrasi, (Jakarta:CV Masaagung, 1990) 5

${ }^{6}$ Syaiful rohim, Teori-Teori Komunikasi Perspektif Ragam dan Aplikasi (Jakarta:rineka cipta2009)8 dan tommy suprapto pengantar teori komunikasi (Yogyakarta:madia pressindo2006)5
} 
untuk dikomunikasikan kemudian disesuaikan dengan saluran alat penerima kemudian alat penerima mengubah sinyal menjadi pesan yang diterima, model ini yang menjadi komunikasi elektronik. Kemudian di kembangkan dengan model Shoemarker yang dikenal dengan (S-M-C-R) yang mana diperlihatkan proses komunikasi merupakan penyimpangan massage dari sumber kepada penerima, tetepi model ini menerima banyak kritik. Pendekatan ini terdiri atas beberapa elemen kunci: sumber (source), pesan (message) dan penerima (receiver) dengan diagram ${ }^{7}$

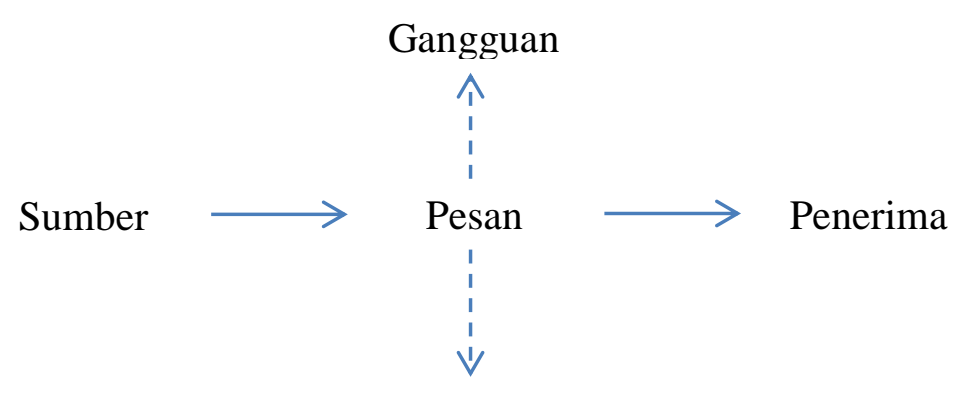

Gangguan

\section{b. Komunikasi Interaksi}

Komunikasi dengan proses sebab akibat atau aksi reaksi yang arahnya bergantian. Komunikasi adalah merupakan suatu proses dimana kita dapat memahami dan dipahami oleh orang lain. Komunikasi merupakan proses yang dinamis dan secara konstan berubah sesuai dengan situasi yang berlaku. ${ }^{8}$

c. Komunikasi Transaksi

Komunikasi sebagai transaksi adalah komunikasi yang tidak membatasi pada komunikasi yang disengaja atau respon yang dapat diamati. Artinya komunikasi

\footnotetext{
${ }^{7}$ Syaiful rohim, Teori-Teori Komunikasi Perspektif Ragam dan Aplikasi (Jakarta:rineka cipta2009)14

${ }^{8}$ Ibid 10
} 


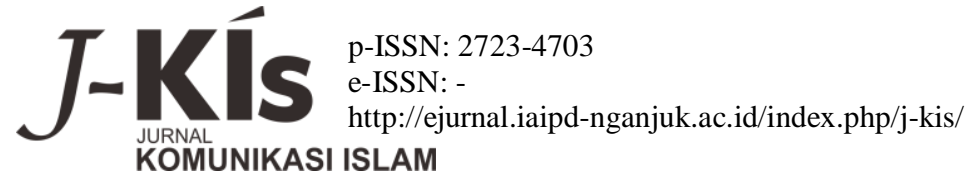

terjadi apakah para pelaku menyengajanya atau tidak, dan bahkan meskipun menghasilkan respon yang dapat diamati. ${ }^{9}$

William G Scott mengatakan bahwa terdapat 5 faktor yang mempengaruhi proses komunikasi: ${ }^{10}$

a. The Act ( perbuatan)

b. The scane ( Adegan) yang menekankan pada hubungan dengan lingkungan komunikasi

c. The Agent (Pelaku) individu yang mengambil bagian dalam hubungan.

d. The agency (perantara) media yang membantu sebagai perantara komunikasi

e. The purpose (Tujuan) yang diklasifikasikan dalam tujuan fungsional ( sebagai tujuan organisasi), tujuan manipulasi (menggerakkan orang untuk menerima ide baik memiliki nilai atau tidak memiliki), tujuan keindahan (tujuan yang bersifat kreatif), tujuan keyakinan (untuk menyakinakan dan mengembangkan keyakinan orang-orang di lingkungan)

Komunikasi adalah proses menciptakan dan saling menukar pesan dalam satu jaringan hubungan saling ketergantungan satu dengan yang lain untuk mengatasi lingkungan yang selalu berubah-ubah. Definisi ini mengandung tujuan, konsep kunci yaitu proses, pesan, jaringan, saling ketergantungan, hubungan, lingkungan dan ketidakpastian. Konsep kunci tersebut diantaranya: ${ }^{11}$

a. Proses

adalah sistem terbuka yang dinamis yang menciptakan dan saling menukar pesan diantara anggotanya. Karena segala menciptakan dan menukar informasi ini berjalan terus-menerus dan tidak berhenti makanya dikatakan suatu proses.

b. Pesan

adalah susunan simbul yang penuh tentang orang, objek, kejadian yang dihasilkan oleh interaksi dengan orang dan orang tersebut harus menyusun gambaran mental, memberikan gambaran. Komunikasi tersebut efektif kalau pesan yang dikirim itu diartikan sama dengan apa yang dimaksud pengirim. Menurut bahasa pesan

\footnotetext{
${ }^{9}$ Ibid 10

${ }^{10}$ Tommy Suprapto, Pengantar Teori Komunikasi ( Yogyakarta: Media Presindo 2006)8-9

${ }^{11}$ Arni Muhammad, Komunikasi Organisasi ( Jakarta: Bumi aksara 2001)67-191
} 
diklasifikasikan pesan verbal dan non verbal, dan diklasifikasikan menurut penerima pesan adalah pesan internal dan eksternal, pesan dapat pula dilasifikasikan menurut cara penyebaran pesan melalui perangkat keras atau perangkat lunak.

c. Jaringan

adalah ciptaan dan pertukaran pesan kecil dari seseorang dengan sesamanya yang melewati suatu set yang dinamakan jaringan komunikasi.

Dalam komunikasi Islam terdapat tiga bentuk komunikasi diantaranya: ${ }^{12}$

a. Pola komunikasi dengan manusia pilihan

Komunikasi Allah dan manusia yang terjadi secara langsung pernah terjadi pada Nabi Musa as. Sedangkan dengan Nabi yang lain, ALLAH berkomunikasi dengan mereka melewati wahyu, baik yang disampaikan kedalam hati mereka tanpa perantara malaikat atau dengan perantara malaikat. Itulah sebabnya Musa diberi gelar Kalimullah ( orang yang berkomunikasi langsung dengan ALLAH ).

b. Komunikasi dengan Wahyu

Komunikasi melalui wahyu merupakan jenis komunikasi yang paling lazim pada semua Nabi. Diantara bentuk komunikasi jenis ini terjadi pada Nabi Ibrahim ketika dia meminta ALLAH agar membuktikan kekuasaannya dalam menghidupkan kembali makhluk yang telah meninggal dunia. Diantara komunikasi jenis ini yang dicatat dalam al quran adalah komunikasi antara Nabi Zakaria dengan penciptanya. Komunikasi juga terjadi antara Nbai Isa dengan penciptanya. Al quran merekam komunikasi ini dlama surah al maidah 116 - 118. Pola komunikasi dengan perantara wahyu terhenti dengan di utusnya Nabi Muhammad sebagai Nabi terakhir yang di utus ke muka bumi.

c. Pola Komunikasi dengan Manusia Biasa

Setelah manusia lahir ke dunia, ALLAH sudah menyiapkan berbagai media yang memungkinan mereka untuk tetap bersambung dnegan ALLAH diantaranya dengan Sholat, Dzikir, Istighfar dan Taubat, Tilawah Al Quran

\section{Strategi komunikasi}

\footnotetext{
${ }^{12}$ Harjani hefni, Komunikasi Islam (Jakarta: Kencana 2003)
} 
Demikianlah pula strategi komunikasi merupakan paduan dan perencanaan komunikasi (communication planning) dan manajemen komunikasi (communication management) untuk mencapai suatu tujuan. Untuk mencapai tujuan tersebut strategi komunikasi harus dapat menunjukan bagaimana operasionalnya secara taktis harus dilakukan dalam arti kata bahwa pendekatan (approach) bisa berbeda sewaktu-waktu bergantung dari situasi dan kondisi.

Strategi komunikasi merupakan penentu berhasil tidaknya kegiatan komunikasi secara efektif. Dengan demikian, strategi komunikasi, baik secara makro (plammed multi-media strategi) maupun secara mikro (single communication medium strategi) mempunyai fungsi ganda :

a. Menyebarluaskan pesan komunikasi yang bersifat informatif, persuasif dan instruktif secara sistematik kepada sasaran untuk memperoleh hasil optimal.

b. Menjembatani "cultural gap" akibat kemudahan diperolehnya dan kemudahan dioperasionalkannya media massa yang begitu ampuh yang jika dibiarkan akan merusak nilai-nilai budaya.

Dari kedua tujuan tersebut, dapat disimpulkan bahwa sebuah strategi komunikasi bertujuan menciptakan pengertian dalam berkomunikasi, membina dan memotivasi agar dapat mencapai tujuan yang diinginkan pihak komunikator. Berbicara mengenai strategi komunikasi, Chriss Fill, membagi strategi komunikasi menjadi 3 teori utama, yaitu:

a. Pull Strategy: strategi komunikasi dimana proses komunikasi menekankan pada keberhasilan meraih khalayak sebanyak mungkin tujuannya adalah untuk meningkatkan kesadaran (awareness) dan mengarahkan perilaku (attitude) khalayak untuk menghasilkan produk dan masuk kedalam jaringan perusahaan (menjadi konsumen).

b. Push Strategy: strategi komunikasi yang menitikberatkan pada jaringan kemampuan kerja. Proses komunikasi tidak hanya mengandalkan pada pemberian informasi persuasif, tetapi juga mampu meningkatkan koordinasi dan partisipatif aktif karyawan serta integritas seluruh karyawan. Strategi ini mengarah pada terwujudnya kekuatan untuk mendorong loyalitas dan komitmen karyawan. 


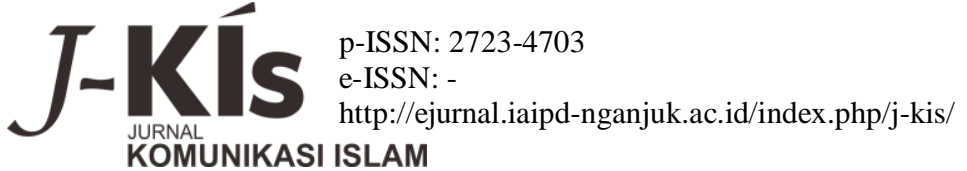

c. Profile Strategy: komunikasi untuk mempertahankan image perusahaan. proses komunikasi menekankan pada pengelolaan identitas perusahaan yang bertujuan untuk menjaga hubungan dengan relasi dan stakeholder perusahaan.

Komunikasi memiliki peran yang penting terhadap analisa nilai-nilai dalam sebuah timbal balik komunikasi (reciprocal) atau seberapa banyak yang lebih bersifat searah. Dalam hubungan ini adalah untuk mengingatkan masyarakat akan perlunya komunikasi inter-subjectif. Hal mana yang menjamin proses komunikasi yang demokratis yang mencerminkan penghargaan terhadap manusia sebagai makluk tuhan yang bermartabat. $^{13}$

Komunikasi merupakan suatu proses dimana komponen-komponen (sumber, penerima dan pesan) saling terkait dan para komunikator saling beraksi dan bereaksi sebagai kesatuan dan keseluruhan. Esensi dalam proses komunikasi adalah memperoleh kesamaan makna diantara orang-orang yang terlibat dalam komunikasi. Komunikasi memiliki sifat subjektif, yang memiliki persepsi terhadap objek dalam lingkungan kita, tindakan meng-encoding pesan semuanya dipengaruhi oleh budaya manusia itu tinggal.

Dalam kajian komunikasi Islam dipaparkan bahwa terdapat tiga bentuk komunikasi diantaranya : komunikasi manusia dengan Allah, komunikasi manusia dengan dirinya sendiri dan komunikasi dengan yang lain. Dengan memiliki pola komunikasi langsung, komunikasi Allah dan manusia terjadi secara langsung yang pernah terjadi pada nabi Musa As. (Kalimatullah) sedangkan nabi-nabi yang lain Allah berkomunikasi melalui perantara wahyu, baik tanpa perantara malaikat atau dengan perantara malaikat. Nabi Muhammad memiliki dua pola kumunikasi dimana komunikasi secara langsung ketika berada di sidrotul muntaha dan komunikasi melalui wahyu dimana al qur'an diturunkan. ${ }^{14}$

Dipaparkan pula prinsip - prinsip dasar komunikasi dalam Islam diantranya:

a. Prinsip Pertama : Prinsip Ikhlas

Ikhlas adalah kerja hati. Ikhlas menurut istilah adalah kerja yang dilakukan oleh hati untuk mensucikan dirinya dari berbagi motif yang tidak benar. Prinsip ikhlas ini

\footnotetext{
${ }^{13}$ Phil. Astrid S. Susanto, Komunikasi Massa (bandung: Angkasa offset 1982)9

${ }^{14}$ Harjani hefni
} 
adalah prinsip yang paling mendasar dalam komunikasi islam. Kehilangan prinsip ini dari komunikator meaupun komunikan akan membuat tujuan utama komunikasi yaitu badah menjadi hilang dan kekuatan pesan yang disampaikan memudar. Kehilangan prinsip ini dari salah satu pihak akan membuat proses komunikasi terhambat apalagi bertemu antara ketidakikhlasan komunikator dengan komunikan. Selain faktor penerima pesan, kekuatan pesan juga dipengaruhi oleh keikhlasan pengirim pesan. Ikhlas dalam komunikasi adalah pilar utama utnuk mendapatkan komunikasi yang berkualitas : mendapatkan pahala, selektif dan produktif.

b. Prinsip kedua : Prinsip Pahala dan Dosa

Prinsip ini menjelaskan bahwa setiap pesan atau pernyataan yang keluar itu mengandung konsekuensi pahala atau dosa. Lisan memiliki peran kunci dalam berkomunikasi, apakah mengantar kepada kesuksesan atau kehancuran.

c. Prinsip Ketiga : Prinsip Kejujuran

Di antara bentuk kejujuran dalam berkomunikasi adalah Tidak memutarbalikkan fakta, Tidak berdusta.

d. Prinsip Keempat : Prinsip Kebersihan

Islam sangat menekankan prinsip kebersihan dalam segala hal, termasuk dalam menyampaikan pesan. Pesan yang baik akan mendatang kenyamanan psikologis bagi yang menerimanya, sedangkan pesan yang jorok, sarkatis, berdarah - berdarah, pertengkaran, perselingkuhan akan berdampak pada keruhnya hati.

e. Prinsip Kelima : Prinsip Berkata Positif

Pesan yang diungkapkan dengan bahasa yang penuh optimis membangkitkan semangat untuk melakukan perubahan

f. Prinsip KeEnam : Prinsip Paket ( Hati, Lisan dan Perbuatan )

Manusia adalah makhluk yang diciptakan Allah dalam satu paket lengkap. Ada unsur jiwa dan raga. Gerak raga dalam konsep islam dipengaruhi secara kuat oleh hati atau jiwa. Artinya, lisan akan berbicara yang baik manakala hatinya baik, dan lisan tidak akan mampu berbicara dengan baik dan lancar tanpa kendali dari jiwanya, yang diucapkannya akan terasa hambar. Rasulullah SAW bersabda yang artinya : 
“ ketahuilah, bahwa ditubuh itu ada satu gumpalan daging, apabila ia baik maka baiklah seluruh jasad, dan apabila ia rusak, maka rusak lah jasad, ketahuilah itu adalah hati “

g. Prinsip Ketujuh : Prinsip Dua Telinga Satu Mulut

Menceritakan kembali semua yang didengar adalah tanda kecerobohan seseorang. Tidak semua informasi yang sampai kepada seseorang dipahami secara benar, atau dipahami secara benar tapi beritanya tidak benar, atau beritanya benar tidak layak dikonsumsi oleh masyarakat. isyarat agar kita berhati - hati dalam berbicara dan banyak mendengar adalah pada struktur fisik kita yang diciptakan dengan dua telinga dan satu mulut.

h. Prinsip Kedelapan : Prinsip Pengawasan

Prinsip pengawasan muncul dari kepercayaan mukmin yang meyakini bahwa Allah maha Mendengar, Maha Meliat dan Maha Mengetahui. Prinsip pengawasan ini akan membuat orang lain selalu merasa diperhatikan dan dipantau. Orang yang selau merasa dipantau biasanya lebih berhati - hati dalam mengeluarkan statement.

i. Prinsip Kesembilan : Prinsip Selektifitas dan Validitas komunikasi islam bukan hanya bertujuan untuk memberikan kepuasan bagi komunikan didunia ini, tetapi tujuan utama mereka adalah agar bisa mempertanggungjawabkan apa yang mereka kemukakan pada saat diminta pertanggungjawaban diakhirat.

j. Prinsip Kesepuluh : Prinsip Saling mempengaruhi

Saat berlangsung komunikasi, proses pengaruh mempengaruhi terjadi. Karena muara semua tujuan komunikasi adalah saling mempengaruhi, maka membangun komunikasi yang bertujuan untuk menciptakan suasana yang sehat adalah bagian yang tidak terpisahkan dari islam. Diantara bentuk pengaruh strategis komunikasi adalah Dapat merubah pendapat orang lain, menjadi faktor yang menentukan baik buruknya manusia.

k. Prinsip Kesebelas : Prinsip Keseimbangan

Informasi yang seimbang akan membuat keputusan menjadi akurat. Prinsip keseimbangan dalam menyerap informasi sebelum memberikan sikap adalah 


\section{$\int \begin{aligned} & \text { p-ISSN: 2723-4703 } \\ & \begin{array}{l}\text { e-ISSN: - } \\ \text { http://ejurnal.iaipd-nganjuk.ac.id/index.php/j-kis/ }\end{array} \\ & \text { KURNALUNIKASI ISLAM }\end{aligned}$}

keharusan. Dengan prinsip ini, informasi yang kita terima akan lebih akurat, karena pihak yang sedang berselisih kadang - kadang memberikan informasi secara emosional dan berlebihan.

1. Prinsip Keduabelas : Prinsip Privasi

Setiap orang memiliki ruang privasi yang tidak boleh diungkap dipentas publik, begitu juga dengan organisasi, lembaga dan seterusnya. Allah melarang orang beriman untuk mencari - cari informasi tentang masalah - masalah yang masuk dalam ruang privasi. Diantara indikator sebuah informasi tidak untuk dikonsumsi publik adalah bahasa tubuh dari orang yang menyampaikan pesan. Melanggar masalah privasi seperti ini di dalam islam masuk dalam status pelanggaran hak - hak asasi manusia yaitu melakukan pencemaran nama baik.

\section{DISKUSI}

Dalam Qs al-alaq atau surat yang pertama kali diturunkan menjelaskan strategi komunikasi antara Allah dan rosul, itu terbukti setelah turunnya wahyu tersebut Allah memerintahkan rosul untuk membaca melalui kalamnya dengan perantara jibril, dengan penyampaian pesan melalui kalamnya berarti merupakan proses komunikasi dimana yang nantinya digunakan sebagai penyampaian nilai-nilai dan pengambilan keputusan untuk melakukan perubahanan sosial pada umat Muhammad. Pertama rosulullah diberikan pengetahuan tentang manusia,

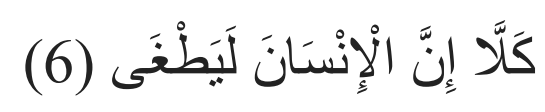

"sesunggunya manusia benar-benar melampaui batas" qs al alaq 6-8

Dalam ayat tersebut sesuai dengan asbabul nuzulnya ayat tersebut Allah telah memberikan gambaran melalui pengalaman yang nyata mengenai abu jahal yang telah melampaui batasannya.

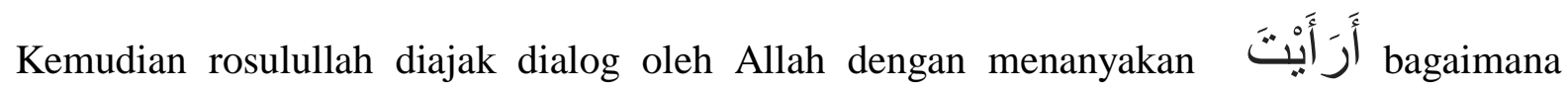
pendapatmu?" qs al alaq 9,11,13 setelah menanyakan pendapat kemudian Allah memberi pengetahuan atau arahan kepada nabi muhammad

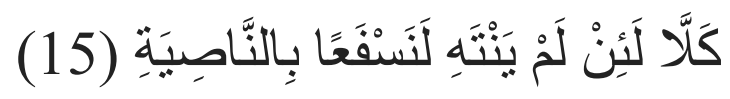




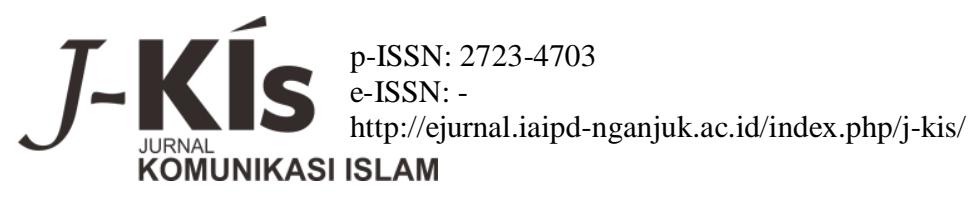

Ketahuilah, sungguh jika dia tidak berhenti (berbuat demikian) niscaya kami tarik ubunubunnya $[* * *]$

"ketahuilah" yang terakhir kalimat peringatan, dari asbabul wurudnya diketahui bahwa setelah diajak berdialog oleh Allah tubuh nabi seraya bergetar dan menyuruh istrinya (khodijah) untuk menyelimuti badannya. Dan yang terakhir adalah memberi peringatan

$$
\text { أَلَمْ بَعْلَمْ بِانَنَّ اللَّهَ بَرَى (14) }
$$

14. Tidaklah dia mengetahui bahwa sesungguhnya Allah melihat segala perbuatannya?

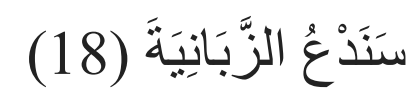

18. Kelak kami akan memanggil malaikat Zabaniyah [****],

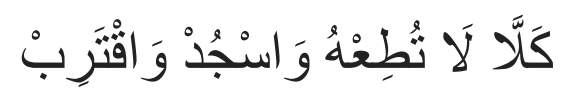

19. Sekali-kali jangan, janganlah kamu patuh kepadanya; dan sujudlah dan dekatkanlah (dirimu kepada Tuhan)

\section{METODE PENELITIAN}

Penelitian ini termasuk dalam jenis penelitian teoritis yaitu studi kepustakaan (Library Research) yaitu studi kepustakaan. Hal ini dimaksudkan untuk menghimpun data dan informasi lain yang mempunyai kaitan dengan topik penelitian ini. Kajian pustaka yaitu penampilan argumentasi penalaran keilmuan yang memaparkan hasil penelitian pustaka dan hasil pemikiran peneliti mengenai suatu masalah (topik), hasil kajian pustaka semacam ini berisi satu topik yang didalamnya memuat beberapa gagasan dan informasi dari sumber pustaka (literature), bahanbahan pustaka yang dipakai harus dibahas secara kritis dan mendalam dalam rangka mendukung gagasan atau proposisi untuk menghasilkam kesimpulan dan saran. Dari istilah diatas dapat dikatakan pula bahwa penelitian ini merupakan penelitian yang lebih berorientasi pada penggalian data, atau tepatnya referensi yang berasal dari karya ilmiah, atau karya tulis yang sudah ada sebelumnya. 


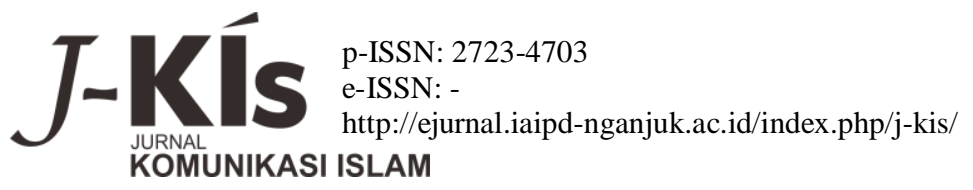

Sumber data adalah subyek dari mana data dapat diperoleh, sumber data ini meliputi data primer dan data sekunder : 1) Sumber Data Primer yaitu bahan pustaka yang berisikan pengetahuan ilmiah yang baru atau mutakhir, ataupun pengertian baru tentang fakta yang diketahui maupun mengenai gagasan (ide). Adapun sumber primer yang digunakan dalam penelitian ini yang digunakan adalah buku, jurnal ilmiah, buletin dan sebagainya. 2) Sumber Data Sekunder yaitu bahan pustaka/sumber data sebagai penunjang dalam skripsi ini, seperti semua buku yang ada hubungannya dengan judul skripsi ini secara tidak langsung.

Metode dan instrumen pengumpulan data yang digunakan dalam kajian ini adalah metode dokumentasi yaitu cara pencarian data dari hal-hal yang akan dibahas ataupun teori-teori yang akan digunakan dalam rumusan data yang kemudian disimpulkan. Data ini dapat berupa transkip, cacatan, majalah, prasasti, dan sebagainya.

Teknik analisa data yang digunakan yaitu content analysis yaitu metode yang lebih mengedepankan pada pengungkapan aspek isi (esensi) dari beberapa proposisi yang ada. Lebih lanjut metode ini merupakan watak dari peninjauan berbagai teori dan analisis. Kajian isi sebagai teknik penelitian untuk keperluan mendeskripsikan secara obyektif, sistematis dan kuantitatif tentang manifestasi komunikasi. Weber yang dikutip oleh Soejono dan Abdurrahman menyatakan bahwa content analysis adalah metodologi penelitian dari sebuah dokumen.Kajian isi adalah teknik penelitian yang dimanfaatkan untuk menarik kesimpulan yang replikatif dan sahih dari data atas dasar konteksnya.

\section{HASIL DAN PEMBAHASAN}

\section{Sumber Daya Manusia}

Sumber daya manusia adalah kemampuan terpadu dari daya pikir dan daya fisik yang dimiliki individu. Daya fikir merupakan kecerdasan yang dibawa sejak lahir (modal dasar). Sedangkan kecakapan diperoleh dari usaha (belajar dan pelatihan) atau mengikuti pendidikan. Sedangkan kecerdasan tolok ukurnya adalah kemampuannya dalam menyelesaikan persoalan yang dihadapi yang diukur lewat Intelegence Quotient (IQ). Kecerdasan dan kecakapan individu diimplementasikan untuk menciptakan ide-ide, inovasi, kreativitas, dan kecakapannya dalam bidang yang ditekuninya. Hasan Langgulung menyatakan bahwa Sumber daya manusia adalah bagian atau porsi penduduk produktif yang eksis dalam suatu masyarakat. Ada pula penulis yang mengatakan kata "sumber daya manusia" itu adalah bagian atau porsi penduduk produktif 
$\int \begin{aligned} & \text { p-ISSN: } 2723-4703 \\ & \text { e-ISSN: - } \\ & \text { http://ejurnal.iaipd-nganjuk.ac.id/index.php/j-kis/ } \\ & \text { KURNALUNIKASI ISLAM }\end{aligned}$

eksis dalam suatu masyarakat. Tetapi dengan segera ia menyebutkan bahwa porsi kuantitatif pada sumber daya manusia adalah jumlah penduduk dalam umur 15-65 tahun itu, dan juga tidak usah dipahami sebagai orang-orang yang bekerja dipabrik atau instansi tertentu, karena proses yang memberi input dan menghasilkan output dapat disebut produksi, dimana saja dan siapa saja yang mengerjakannya.

Menurut Wardiman Djojonegoro manusia yang berkualitas adalah manusia yang minimal memiliki kompetensi dalam ilmu pengetahuan (IPTEK), dan kompetensi dalam keimanan dan ketaqwaan kepada Allah SWT. Kompetensi ilmu pengetahuan dan teknologi termasuk kemampuan untuk menghadapi perubahan mencakup, kemampuan memahami hakekat, perubahan dan kemampuan mengelola perubahan sehingga dapat mengambil manfaat dari perubahan tersebut, yaitu menampilkan keunggulan melalui prestasi nyata dalam berbagai bidang kehidupan.

Dalam kehidupan yang serba teknologis ini, manusia dapat mengalami alienasi, manusia tidak lagi hidup secara langsung bebas dengan alam lingkungannya, hidup secara berangsurangsur dikelilingi oleh teknologi, organisasi dan sistem yang diciptakannya sendiri. Memang berkat ilmu pengetahuan dan teknologi, manusia dapat bangkit dari tekanan berat alam yang selalu mengganggunya, akan tetapi secara sistematis mulai tergantung pada hasil ciptaannya dan organisasinya. Dominasi alam dapat dilepaskan, tetapi teknologi dan birokrasinya bangkit dengan dominasi dan kekuatannya yang dahsyat menguasai manusia dan menjadikannya tergantung dan lemah. Alat benar-benar menjadi tuan, sebaliknya manusia adalah hamba yang mengekor, dan merupakan bahaya yang besar manakala ilmu pengetahuan dianggap sebagai satu-satunya metode bagi manusia, sedang wahyu dan firman Allah swt, dinomer duakan atau bahkan dihilangkan dan hancur oleh manusia-manusia yang lupa dengan khaliqnya dan hanya berfikir soal-soal IPTEK. Ilmu pengetahuan pada hakekatnya harus berhubungan erat dengan moralitas manusia, sebab manusia yang mempunyai pengetahuan luas tanpa didasari oleh nilainilai moral dan agama dapat menjadi sombong dan lupa diri.

Dengan demikian peran dari kompetensi iman dan taqwa (IMTAQ) amat penting karena tanpa dibingkai oleh iman dan taqwa, maka kompetensi ilmu pengetahuan dan teknologi akan menjadi kurang bermakna, bahkan dikhawatirkan akan liar dan tidak terkendali yang mewujud dalam bentuk terjadinya erosi nilai-nilai moral. Dipihak lain kompetensi imam dan taqwa tanpa 


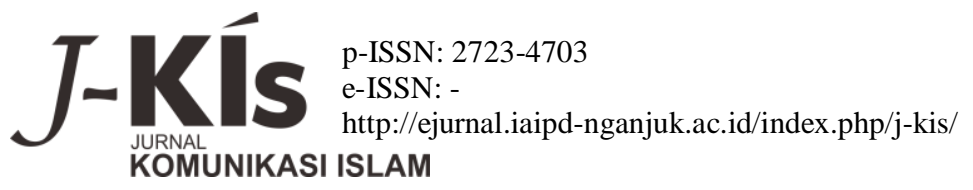

disertai kompetensi ilmu pengetahuan dan teknologi, akan lemah dan tidak berdaya. Sebagai komponen mayoritas bangsa dituntut untuk memiliki dua kompetensi tersebut secara seimbang.

Spiritual manusia yang bersumber pada keimanan dan ketaqwaan, memberikan beberapa macam kesadaran dalam eksistensinya yaitu kesadaran akan hidupnya yang terbatas, kesadaran akan pencarian makna hidup, kesadaran akan pendayagunaan nikmat dan mensyukurinya dan kesadaran akan kemungkinan terjadinya kelalaian karena terkecoh godaan. Dengan kesadarankesadaran tersebut manusia akan mengetahui kualitas yang ada pada diri yang kemudian menggali segala potensi yang dimilikinya dikemudian hari. Dengan demikian sumber daya manusia (manusia berkualitas) merupakan hal yang sangat penting yang harus dimiliki manusia, tidak hanya dilingkungan industri atau perusahaan tetapi juga organisasi diberbagai bidang baik politik pemerintahan, hukum, sosial budaya, lingkungan dan sebagainya.

Manusia produktif adalah manusia yang realistik dalam menyikapi lingkungannya. Dia sadar akan potensi-potensi yang ada, akan kekurangan-kekurangan serta keterbatasanketerbatasan yang dihadapinya, memahami persoalan dan kebutuhan zamannya. Dengan demikian, Ia mampu menangkap kemungkinan-kemungkinan yang terbentang didepannya. Jadi manusia produktif mempunyai kemampuan diri yang dapat berguna dalam memberikan sesuatu terhadap dirinya maupun terhadap orang lain baik dari segi pemikiran atau hasil karyanya untuk kemakmuran dan kesejahteraannya. Contohnya seorang ibu rumah tangga itu produktif, sebab ia mengerjakan pekerjaan rumah tangga yang nilainya sama atau lebih baik dari hasil kerja yang dihasilkan oleh pembantu rumah. Malah seorang anak kecilpun dapat dianggap produktif terhadap ibu dan ayahnya sebab ia dapat memberikan kebahagiaan pada diri yang pada gilirannya bisa menambah semangat kerja pada ibu dan ayahnya, sebab mendapat kebahagiaan yang disebabkan olehnya. Pendeknya semua orang itu produktif, kecil ataupun besar, lelaki atau perempuan, terdidik atau tidak terdidik, masing-masing memiliki cara untuk memberi input dan output dalam konteks yang menyeluruh.

Manusia merupakan sumber daya paling penting dalam usaha organisasi mencapai keberhasilan, sumber daya ini menunjang organisasi dengan karya, bakat, kreativitas dan dorongan. Betapapun sempurnanya aspek teknologi dan ekonomi, tanpa aspek manusia sulit kiranya tujuan dapat dicapai. Masyarakat telah menunjukkan perhatian yang meningkat terhadap aspek manusia tersebut. Nilai-nilai manusia (human value) semakin diselaraskan dengan aspekaspek tehnologi maupun ekonomi. 
$\int \begin{aligned} & \text { p-ISSN: } 2723-4703 \\ & \text { e-ISSN: - } \\ & \text { http://ejurnal.iaipd-nganjuk.ac.id/index.php/j-kis/ } \\ & \text { KURNALUNIKASI ISLAM }\end{aligned}$

Adapun sumber daya manusia yang berkualitas menurut Muhammad Sirozi dikutip dari Karel Rogerz menjelaskan sumber daya manusia yang berkualitas adalah yang memiliki kepribadian seimbang, yaitu: 1) Bersikap terbuka, menerima berbagai pengalaman, dan berusaha memahami perasaan-perasaan internalnya, 2) Hidup secara eksistensialistik, yakni memiliki kepuasan batin bahwa tiap saat ia menginginkan pengalaman baru. Ini berarti memiliki perasaan internal bahwa ia bergerak dan tumbuh, 3) Dalam srtuktur keanggotaannya, ia menemukan hal yang dipercaya untuk mencapai tingkah laku yang paling banyak memberikan kepuasan dalam tiap kondisi nyata. Ia melakukan apa yang dirasakannya benar dalam konteks kekinian. Ia berpegang pada pembentukan totalitas dan komprehensif pada dirinya untuk mengarahkan tingkah laku sesuai pengalaman. Jadi dapat kita tarik kesimpulan bahwa peningkatan sumber daya manusia adalah suatu usaha atau proses yang dilakukan dalam mengembangkan potensi yang terdapat dalam diri manusia untuk menbentuk manusia yang beriman dan bertaqwa kepada Tuhan Yang Maha Esa, cerdas, terampil dan profesional;, kreatif, produktif, berakhlak yang luhur, berkepribadian dan disiplin, sadar akan pengabdian dan punya tanggung jawab sosial serta sehat jasmani dan rohani, sehingga siap untuk menghadapi tantangan zaman.

\section{Pengembangan Sumber Daya Manusia}

Pengembangan sumber daya manusia merupakan pilihan yang memiliki arti strategis bagi bangsa Indonesia karena proses pembangunan nasional harus berkesinambungan dan dinamis meniscayakan adanya sumber daya manusia yang berkualitas, disamping itu sumber daya manusia yang berkualitas akan memungkinkan bangsa Indonesia merebut keunggulan kompetitif atas bangsa-bangsa lain didunia.

Pengembangan sumber daya manusia di masa depan dihadapkan pada era global yang sarat dengan tantangan yang semakin kompleks. Dalam era ini batas-batas politik, ekonomi, dan sosial budaya antar bangsa menjadi begitu transparan sehingga menimbulkan persaingan antar bangsa yang sangat tajam terutama dalam bidang ekonomi serta dalam penguasaan ilmu pengetahuan dan tekhnologi akan dapat mengambil manfaat dari proses ini dapat dicapai terutama dengan peningkatan kualitas SDM yang peka serta mampu memanfaatkan berbagai peluang. Dalam era persaingan global, SDM yang berkualitas adalah mereka yang mampu menguasai suatu bidang keahlian dalam ilmu pengetahuan dan teknologi, mampu melaksanakan 
$\int \begin{aligned} & \text { p-ISSN: 2723-4703 } \\ & \text { e-ISSN: - } \\ & \text { http://ejurnal.iaipd-nganjuk.ac.id/index.php/j-kis/ } \\ & \text { KURNAL }\end{aligned}$

pekerjaan secara profesional, serta mampu menghasilkan karya-karya unggul yang dapat bersaing didunia. Penguasaan terhadap berbagai cabang keterampilan dan keahlian yang sesuai dengan perkembangan iptek mutlak diperlukan dalam rangka menggerakkan berbagai sektor industri dalam rangka meningkatkan nilai tambah dan produktivitas nasional secara berkelanjutan. Pembangunan dengan menekankan pada peningkatan SDM inilah yang akan mendorong terciptanya pertumbuhan ekonomi yang berkelanjutan (sustainable economic growth).

Tantangan lain bangsa dimasa depan bersumber dari perubahan yang terjadi dalam berbagai kehidupan, pada dasarnya perubahan merupakan suatu proses yang berkelanjutan baik yang terjadi secara alamiah maupun dampak dari pembangunan yang sistematis. Perubahan yang terjadi secara menyeluruh dan multidimensional sering berakibat terhadap terjadinya transformasi struktural (structural tranformation). Tranformasi struktural inilah yang memberikan dampak sangat mendasar terhadap terjadinya pergeseran nilai, sikap dan perilaku manusia Indonesia yang sekaligus merupakan tantangan bagi usaha pendidikan.

Dalam rangka pengembangan kualitas SDM ini Indonesia diperkirakan akan dihadapkan pada era transformasi masyarakat Indonesia dari agraris menuju masyarakat industri yang ditandai oleh berbagai perubahan fisik, pranata sosial dan adanya pergeseran nilai sistem. Dan sebagai salah satu indikator dari terjadinya proses tinggal landas. Tranformasi tersebut diakibatkan oleh berkembangnya kegiatan ekonomi industrial dengan teknologi yang tepat guna. Perkembangan industri mengakibatkan munculnya jenis-jenis pekerjaan dan kualifikasi jabatan yang beraneka ragam dan memerlukan jenis-jenis keterampilan dan keahlian baru sesuai dengan perkembangan iptek. Jabatan dan keahlian yang semakin beraneka ragam ini juga akan mengakibatkan timbul berbagai bentuk perubahan fisik, pranata sosial, dan pergeseran sistem nilai. Dengan demikian tidaklah mengherankan jika dalam masyarakat kita akan terjadi semacam benturan antara nilai-nilai tradisional yang melekat pada budaya agraris dengan nilai-nilai budaya industri yang baru berkembang pada sebagian masyarakatnya. Dengan demikian tantangan penting lainnya bagi kita ialah mengembangkan dan menanamkan nilai-nilai budaya industrial yang mampu memacu produktivitas nasional yang tetap berlandaskan nilai-nilai kepribadian bangsa. Dan sasaran utama pengembangan jangka panjang adalah terciptanya kualitas manusia dan kualitas masyarakat Indonesia maju dalam suasana tentram dan sejahtera lahir batin, dalam tata kehidupan masyarakat, bangsa dan negara yang berdasarkan Pancasila, 
$\int \begin{aligned} & \text { p-ISSN: } 2723-4703 \\ & \text { e-ISSN: - } \\ & \text { http://ejurnal.iaipd-nganjuk.ac.id/index.php/j-kis/ } \\ & \text { KURNALUNIKASI ISLAM }\end{aligned}$

selaras dengan hubungan antara sesama manusia, manusia dengan masyarakat, manusia dengan alam lingkungannya, manusia dengan Tuhan Yang Maha Esa.

Sumber daya manusia adalah kekuatan fisik manusia, pengetahuan, keahlian atau keterampilan, semangat dan kreativitas, kepribadian yang dimiliki oleh individu. Sumber daya manusia yang besar jumlahnya dengan kualitas yang relatif rendah merupakan beban yang cukup berat bagi pembangunan Indonesia, karena penduduk yang besar dengan kondisinya yang masih berat kearah sebagai obyek. Permasalahan utamanya adalah bagaimana menjadikan manusia Indonesia dari posisi obyek dan beban pembangunan menjadi subyek dan asset pembangunan. Dengan demikian untuk penyiapan SDM, maka perlu diperhatikan beberapa hal :

1. Disamping adanya keimanan, sumber daya manusia harus mempunyai visi dan misi untuk kemaslahatan (kesejahteraan dan keselamatan dunia dan akhirat) untuk kemaslahatan.

2. SDM yang mampu menciptakan peluang kerja. Ini erat sekali kaitannya dengan penciptaan lapangan pekerjaan dan kualitas produksinya. Ini semua tidak akan terwujud, jika kualitas dan prestasi SDM nya rendah.

3. SDM mampu mewujudkan keadaan masyarakat dan negara yang damai. Ini mencakup SDM teknis dan SDM non-teknis, sebagaimana uraian diatas. Jadi politisi masuk disini.

4. SDM yang bertanggung jawab untuk kemaslahatan umat dan membawa pada meningkatnya iman dan taqwa.

Hal tersebut diatas harus diterapkan agar mampu menghasilkan kemajuan dunia yang meliputi kemajuan ekonomi, sain, tehnologi dan lain-lain. Dalam kenyataannya, manusia yang mempunyai SDM tinggi terkadang berbuat kerusakan, karena keangkuhannya dan kesombongannya. Untuk jenis manusia seperti ini, Alloh memperingatkan dengan keras. Kerusakan juga mungkin terjadi karena mereka yang mempunyai SDM hebat itu telah mengingkari dan bahkan juga memusuhi Allah.

Untuk itu Allah memperingatkan bahwa kerusakan di darat dan dilaut bisa terjadi akibat tangan-tangan manusia. Sudah barang tentu, kita akan sadar hanya tangan-tangan SDM yang berkualitas tinggi yang mampu berbuat kerusakan, bukan mereka yang tidak mempunyai kualitas. Kerusakan ini akan terjadi baik secara langsung menjadi sasaran kerja tangan mereka atau menjadi arena eksperimen kualitas keilmuan kerusakan tersebut. 


\section{Pentingnya Pengembangan dan Peningkatan Sumber Daya Manusia di Era Globalisasi.}

Pengembangan SDM di masa depan dihadapkan pada era global yang sarat dengan tantangan yang semakin kompleks. Dalam era ini batas-batas politik, ekonomi, dan sosial budaya antar bangsa menjdi begitu transparan sehingga menimbulkan persaingan antar bangsa yang sangat tajam terutama dalam bidang ekonomi serta dalam penguasaan ilmu pengetahuan dan teknologi. Negara yang unggul dalam penguasaan ilmu pengetahuan dan teknologi akan dapat mengambil manfaat besar dari proses ini.keunggulan dalam penguasaan iptek ini dapat dicapai terutama dengan peningkatan kualitas SDM yang peka serta mampu memanfaatkan berbagai peluang.

Dalam menghadapi persaingan global yang semakin ketat ini tidak ada pilihan lain bagi Indonesia kecuali membangun sektor-sektor ekonomi dengan erientasi nilai tambah dalam rangka mencapai tingkat produktivitas nasional tinggi. Orientasi nilai tambah tersebut dapat ditingkatkan melalui peningkatan kualitas SDM, yaitu yang terampil dan menguasai iptek yang dibutuhkan untuk mengembangkan sektor-sektor ekonomi produktif.

Globalisasi yang semakin menggejala ini telah mengakibatkan batas-batas politik, ekonomi, dan sosial-budaya antar bangsa menjadi begitu transparan. Globalisasi menimbulkan persaingan antar bangsa yang semakin tajam terutama dalam bidang ekonomi serta bidang ilmu pengetahuan dan teknologi. Hanya negara yang unggul dalam bidang ekonomi dan penguasaan IPTEK sajalah yang akan dapat mengambil manfaat besar bagi globalisasi. Keunggulan dalam bidang ekonomi dan teknologi dapat dicapai terutama dengan SDM yang berkualitas. Jika kualitas SDM kita lemah, maka banyak peluang yang tidak dapat dimanfaatkan secara maksimal, terlewatkan atau terbuang sia-sia.

Telah menjadi kesadaran yang cukup umum bahwa kemajuan suatu bangsa lebih banyak ditentukan oleh sumber daya manusianya daripada oleh alamnya sesuai dengan pendapat Nur Kholis Madjid dalam bukunya Tradisi Islam. Dan hal ini benar karena suatu negara yang mengandalkan sumber daya alamnya yang banyak dan melimpah seperti Saudi Arabia dia menjadi negara yang kaya, tetapi tidak mampu memainkan peranan dalam pengembangan ilmu pengetahuan dan teknologi. Dan pada akhirnya Saudi Arabia tetap menjadi negara konsumen bagi hasil-hasil teknologi Barat. Dan yang mengandalkan potensi atau pengembangan sumber daya manusia seperti Jepang, Inggris dan lain-lain, mereka cenderung cepat perkembangannya baik itu ekonomi maupun teknologi. Dengan demikian kualitas sumber daya manusia merupakan 
$\int \begin{aligned} & \text { p-ISSN: } 2723-4703 \\ & \text { e-ISSN: - } \\ & \text { http://ejurnal.iaipd-nganjuk.ac.id/index.php/j-kis/ } \\ & \text { KURNALUNIKASI ISLAM }\end{aligned}$

aset yang paling penting diantara sumber daya-sumber daya yang lain, dalam setiap usaha memajukan suatu masyarakat atau bangsa.

Dalam rangka mempercepat peningkatan sumber daya manusia yang berkualitas ada beberapa hal yang harus diperhatikan, antara lain sebagai berikut: 1) Pendidikan, yang dapat memberikan kemampuan-kemampuan intelektualitas yang terlibat dalam proses kreatif, 2) Teknologi, yang memberikan kemudahan-kemudahan teknis dan standard kerja yang produktif, 3) kemajuan ekonomi, yang memberikan dampak psikologis untuk menampilkan diri lebih baik dan kebutuhan untuk memperbaiki kesejahteraan masyarakat, 4) Terbukanya mobilitas vertical didalam masyarakat, yang dapat merangsang orang untuk mencapai posisi yang lebih tinggi melalui prestasi-prestasinya. Dengan adanya keempat hal diatas akan terwujudlah cita-cita bangsa yang mempunyai kualitas sumber daya yang berkualitas. Yang mampu berkompetisi dengan negara-negara lain dan dapat mengembangkan potensi-potensi yang diimbangi dengan kualitas dan produktivitas yang tinggi.

Dan yang bertanggung jawab menggarap masalah ini, dipikulkan pada: Pertama: Lembaga keluarga, yang dapat memberikan teladan, etika, disiplin, tata cara berkomunikasi, nilai-nilai agama, kesopanan dan lain-lain. Kedua: Lembaga Pendidikan dan Latihan, yang memberikan pengetahuan, metodologi, motivasi formal, teori-teori dan lain-lain. Ketiga: Lembaga sosial (baik organisasi kemasyarakatan, perusahaan maupun lembaga keagamaan), yang dapat menambah hal-hal yang diberikan oleh kedua lembaga terdahulu, disamping memberikan dorongan atau motivasi dan kesempatan untuk berprestasi. Keempat: Lembaga Pemerintah, untukmemberikan legalitas dan peraturan perundangan yang mendukung terselenggaranya segala upaya pengembangan dan peningkatan sumber daya manusia tersebut, disamping dukungan-dukungan lain. Dengan menggunakan lembaga-lembaga tersebut diatas akan lebih mudah kita dalam meningkatkan SDM yang berkualitas tinggi dan melahirkan potensi manusia yang kreatif, produktif dan berkepribadian.

Peningkatan kualitas sumber daya manusia membutuhkan penguasaan ilmu dan teknologi demikian rupa melalui sistem pendidikan yang memungkinkan untuk pencapaian penguasaan ilmu pegetahuan dan teknologi. Sementara itu kita menghadapi perkembangan mutakhir epistimologi ilmu pengetahuan dan fungsi teknologi yang terikat pada nilai dan fungsinya untuk kepentingan kesejahteraan umat manusia atau bangsa pada khususnya. Dengan perkataan lain, 


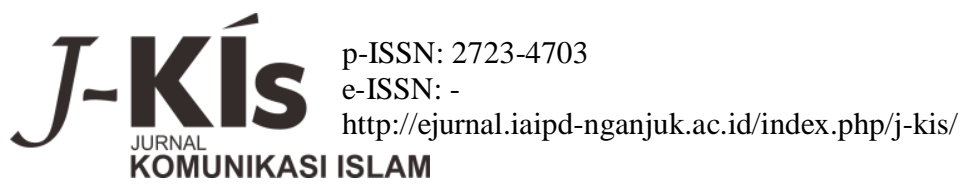

disatu sisi kita menghadapi persaingan untuk menguasai ilmu dan teknologi sehingga sejajar, kalau tidak lebih tinggi dari bangsa lain di dunia, sekaligus kita, disisi lain, menghadapi gelombang yang dahsyat akan keraguan para ilmuwan terhadap konsep, prinsip, metodologi dan fungsi iptek dilihat dari pendekatan integralistik, dan mungkin juga holistik seperti halnya kita menghadapi perubahan dan perkembangan budaya pada pasca modernisme.

Kemajuan teknologi dalam era globalisasi itu mengakibatkan interaksi budaya akan berjalan dengan semakin intensif dan terbuka, sehingga berdampak pada terjadinya perubahan budaya yang amat fundamental. Itulah globalisasi budaya yang menyebabkan terjadinya perubahan pola dan gaya hidup, bahkan nilai-nilai dan tatanan kehidupan manusia di dunia, tak terkecuali di Indonesia. Oleh karena itu, perlu kita sadari bahwa globalisasi tidak selalu membawa dampak positif bagi umat manusia, bahkan tampaknya akan menjadi semacam "ideologi baru" yang siap menerkam nilai-nilai dan tatanan kehidupan kita bermasyarakat, berbangsa dan bernegara.

Dalam globalisasi budaya ini, paling tidak ada tiga hal kehidupan kita yang berubah dan cenderung terus berubah, yaitu budaya 3-F: budaya makan (food), budaya berbusana (fashion), dan budaya untuk memenuhi kesenangan hidup (fun). Ini bukan suatu yang enteng dan juga tidak main-main, karena akibatnya akan cukup besar terhadap tatanan kehidupan sosial ekonomi bangsa kita. Ambil saja contoh dalam hal makanan. Budaya makan kita sudah mulai terjajah oleh budaya makan dari luar . Buah kiwi lebih dikenal daripada buah sawo, dan salad lebih dikenal daripada gado-gado. Apabila pola makan asing menjadi budaya makan masyarakat kita, maka demand terhadap makanan asing akan meningkat. Dikarenakan produk makanan asing itu tidak dapat sepenuhnya dihasilkan didalam negeri, maka impor akan meningkat. Pada gilirannya, struktur produksi nasional kita akan tergantung kepada komponen luar, sehingga tidak mendorong produksi dalam negeri. Devisa juga akan bocor dan mengalir keluar. Akibatnya lebih jauh adalah pendapatan nasional berkurang sehingga pembangunan akan terancam kemandegan. Bayangkan, betapa berat konsekuensi yang harus kita tanggung apabila 3-F (food, fashion, dan fun) bangsa kita dijajah oleh budaya asing. Moral dan jati diri kita sebagai bangsa Indonesia akan terancam. Dan kita harus pandai memilih dan memilah. Dengan demikian kita harus memperkukuh moral dan budaya bangsa tanpa mengabaikan peningkatan daya saing, meningkatkan penguasaan ilmu pengetahuan dan teknologi dalam rangka mengembangkan kualitas sumber daya manusia. 
$\int \begin{aligned} & \text { p-ISSN: } 2723-4703 \\ & \text { e-ISSN: }- \\ & \text { http://ejurnal.iaipd-nganjuk.ac.id/index.php/j-kis/ } \\ & \text { KURNAL }\end{aligned}$

Telah menjadi kesadaran yang cukup umum bahwa kemajuan suatu bangsa lebih banyak ditentukan oleh sumber daya manusianya daripada oleh alamnya. Tetapi sumber daya manusia disini tidak hanya kita pandang sebagai "faktor produksi" setara dengan sumber daya lain, karena manusia adalah makhluk Tuhan yang paling sempurna wujudnya. Hal ini jelas karena akal kreatif manusia (potensi akal) dan rasa ekspresinya (potensi qalbu) menjadikannya mampu mempertahankan eksistensinya sebagai pembawa amanah "ibadah" dan sekaligus "khalifah" ditengah-tengah posisinya yang unik dalam sistem kemakhlukan dan posisinya yang menonjol dalam hubungan dengan Tuhan. Manusia yang mampu mengembangkan sumber dayanya seperti itu yang mendapat konsesi luas dari Tuhan untuk menundukkan dan mendaya gunakan sumber daya-sumber daya lain, baik sumber daya alam, maupun sumber daya teknologi, bahkan mungkin sumber daya supranatural yang tidak teridentifikasi.

Untuk meningkatkan kualitas manusia dan sumber dayanya yang perlu diperhatikan pada umumnya ada 4 (empat) dimensi, yakni:

\section{Dimensi Kepribadian}

Yaitu merupakan hasil suatu proses sepanjang hidup yang dilalui seseorang yang berbeda dalam menentukan tingkah laku yang sempurna baik jasmani maupun rohani. Pembentukan kepribadian itu ditentukan oleh pengetahuan seseorang ( sikap, jujur, sopan, tindakan sehari-hari) msehingga individu dapat menyesuaikan diri dengan lingkungannya.

Malayu menulis bahwa kepribadian adalah serangkaian ciri yang relatif tetap dan sebagian besar dibentuk oleh faktor keturunan, sosial, kebudayaan, dan lingkungan. Dibawah sketsa tentang kekuatan-kekuatan yang mempengaruhi kepribadian:

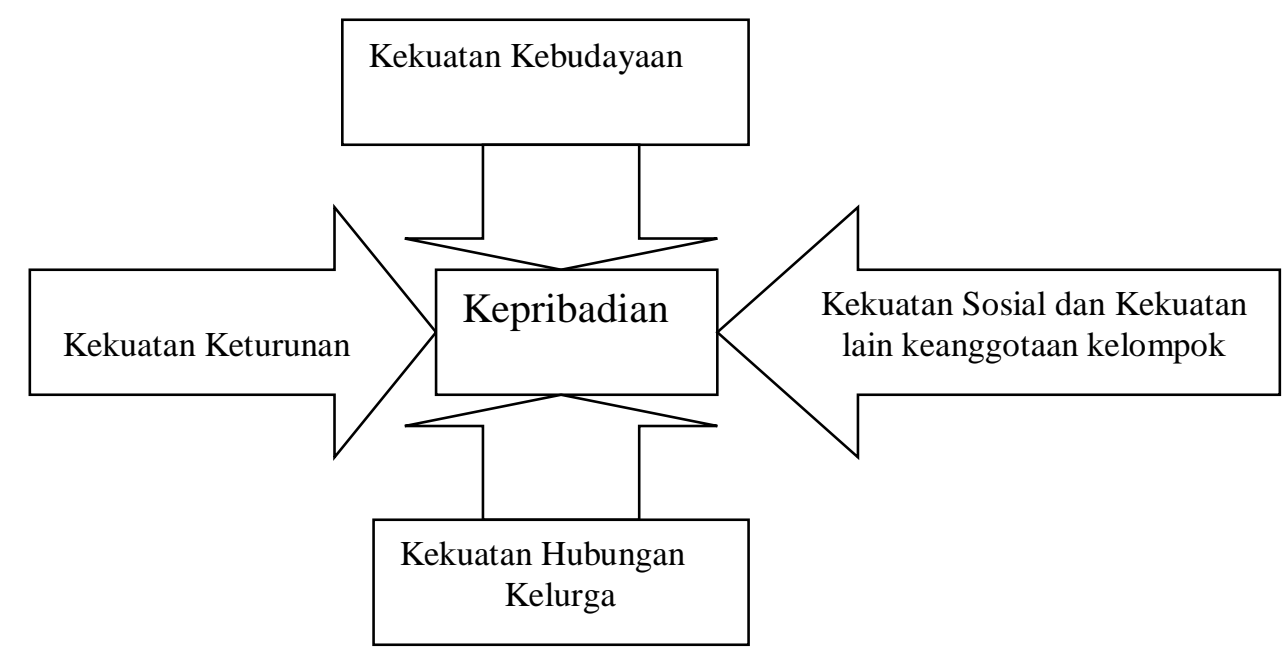


$\int \begin{aligned} & \text { p-ISSN: } 2723-4703 \\ & \text { e-ISSN: - } \\ & \text { http://ejurnal.iaipd-nganjuk.ac.id/index.php/j-kis/ } \\ & \text { KURNALUNIKASI ISLAM }\end{aligned}$

Gambar 2.1

Kekuatan-kekuatan yang mempengaruhi kepribadian

Kekuatan-kekuatan utama yang mempengaruhi kepribadian seseorang adalah kekuatan keturunan, kekuatan budaya, kekuatan hubungan keluarga dan kelas sosial atau pendidikan, dan kekuatan lain dari keanggotaan kelompok. Kekuatan-kekuatan utama yang mempengaruhi kepribadian digambarkan pada konsep Gambar 2.1.

Pertumbuhan dan perkembangan hidup umat manusia dari generasi ke generasi tidak terlepas dari proses pembentukan dan pembinaan kepribadian, yang kemudian saling memberikan pengaruhnya dalam kehidupan bersama.

Dalam pembentukan kepribadian banyak faktor yang ikut mempengaruhinya, antara lain adalah lingkungan, seperti penyesuaian terhadap lingkungan. Proses pembentukan yang dialami seseorang itu berbeda-beda, maka kepribadian tiap-tiap individupun berbeda-berbeda, antara individu yang satu dengan yang lain, sehingga bersifat unik. Tidak ada kepribadian yang sama antara seseorang dengan orang lainnya di dunia ini yang sama, meskipun saudara kembar dari satu rahim ibu, karena manusia hidup didunia ini dapat sistematis dan berencana tergantung pada diri seseorang dengan lingkungannya dan seseorang itu dapat mengupayakan terbentuknya satu sikap kepribadian yang diharapkan.

Ada beberapa proses pembentukan kepribadian, yaitu kepribadian terbentuk setelah mengikuti proses sebagai berikut:

a. Adanya nilai yang diserap seseorang dari berbagai sumber, mungkin agama, ideologi, pendidikan, temuan sendiri, atau lainnya.

b. Nilai membentuk pola pikir seseorang yang secara keseluruhan keluar dalam bentuk rumusan visinya.

c. Visi turun ke wilayah hati dan membentuk suasana jiwanya yang secara keseluruhan keluar dalam bentuk mentalitas.

d. Mentalitas mengalir memasuki wilayah fisik dan melahirkan tindakan yang secara keseluruhan disebut sikap.

Sikap-sikap yang dominan dalam diri Dari analisis diatas dapat dianalisa bahwa startegi komunikasi yang digunakan Allah kepada rosulnya yang pada waktu itu rosulullah masih dikatakan uumi, bisa digunakan sebagai contoh strategi komunikasi kepada masyarakat pada umumnya strategi tersebut diantaranya: 


\section{Tahap pertama; Memberikan pengetahuan terlebih dahulu.}

Dikatakan bahwa memberikan gambaran tentang manusia yang apa diketahui oleh nabi Muhammad (sesuai dengan experience -nya) pengalaman hidupnya dalam hadis dijelaskan tentang pengetahuan manusia yang buruk akhlaknya (abu jahal) dengan menggunakan media kalam.

Memberikan pengetahuan merupakan suatu strategi yang digunakan sebagai pilihan alternatif yang digunakan untuk membuat suatu perencanaan dalam manajemen yang digunakan sebagai bentuk pengambilan keputusan dan peta jalan menuju suatu perubahan.

\section{Tahap kedua: Mengajak berdialogue}

Sesuai yang dijelaskan dalam kata أَرَأَبْبَ qs al alaq 9,11,13 pertanyaan bagaiman sampai diulang 3 kali yang berarti menanyakan pendapat, dalam hal ini terjadi dua arah atau yang disebut dengan dialog. Yang merupakan bentuk komunikasi dua arah yang merupakan interaksi antara Allah dengan Rosulullah "Komunikasi dengan proses sebab akibat atau aksi reaksi yang arahnya bergantian. Komunikasi adalah merupakan suatu proses dimana kita dapat memahami dan dipahami oleh orang lain. Komunikasi merupakan proses yang dinamis dan secara konstan berubah sesuai dengan situasi yang berlaku."

Berdialok merupakan esensi dalam proses komunikasi dimana digunakan untuk memperoleh kesamaan makna diantara orang yang terlibat komunikasi yang bersifat subjektif yang memiliki persepsi objek dalam lingkungan yang meng-ecoding pesan yang dipengaruhi budaya manusia.

\section{Tahap ketiga:Memberikan pemahaman}

Setelah proses dialog ada kata كَ كََّّ yang berarti "ketahuilah" makna tersebut lebih memberikan pemahaman terhadap rosulullah tentang hasil dialog tersebut Memberikan pemahaman merupakan bagian dari komunikasi interaksi dimana nabi dapat memahami dan dipahami apa yang diisyaratkan oleh Allah. Komunikasi ini merupakan suatu proses yang dinamis.

\section{Tahap keempat sampai pada memberikan peringatan}




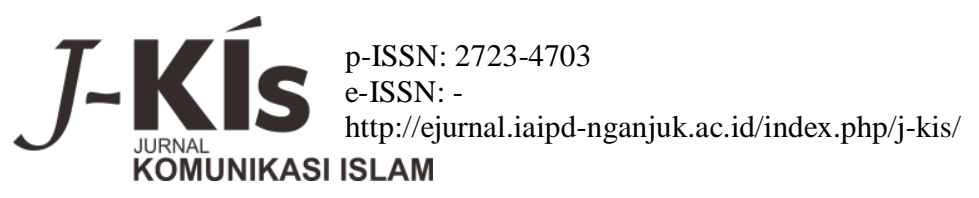

Dan yang terakhir adalah sampai adanya suatu peringatan terhadap hasil yang didialokkan yang diketahui dalam ayat 14, 18, 19.

Memberikan pering merupakan komunikasi yang dapat mempengaruhi, perbuatan, adegan, pelaku, perantara, dan tujuan yang ingin dicapai dan dikomunikasikan oleh Allah. Seperti yang di paparkan W.G Scott yang dinyatakan empat tujuan dan tujuan ini dapat diklasifikasikan dalam tujuan keyakinan (untuk menyakinkan dan diyakinkan orang di lingkungannya)

Bentuk strategi ini bisa disingkronkan dalam teori komunikasi adalah merupakan strategi komunikasi pull strategi dimana proses komunikasi yang menekaknkan pada keberhasilan meraih khalayak sebanyak mungkin yang tujuannya meningkatkan kesadaran dan mengarahkan perilaku, dengan menganalisa nilai-nilai yang ditunjukan yang menciptakan pengertian dalam komunikasi membina dan memotivasi agar dapat mencapai tujuan yang diinginkan komunikator

e. Pola komunikasi nabi Muhammad dengan Allah memiliki dua pola komunikasi yaitu pola komunikasi langsung dan tidak langsung dan memiliki semua prinsip dalam komunikasi tetapi yang ditekankan dalam strategi komunikasi ini adalah prinsip mempengaruhi dimana menciptakan hubungan yang sehat yang berbentuk pengaruh strategi komunikasi yang dapat merubah pendapat orang menjadi faktor baik dan buruknya manusia

f.

\section{KESIMPULAN}

Strategi merupakan suatu perencanaan yang digunakan untuk mencapai suatu tujuan, sedangkan komunikasi adalah penyampaian pesan yang digunakan sebagai proses pengambilan keputusan bersama untuk membentuk perubahan sosial yang memiliki fungsi menyebarluaskan pesan komunikasi yang menjembatani culture gab.

Didalam strategi komunikasi antara Allah dan Rosullnya dapat dianalisis kedalam empat bagiaan diantaranya tahapan pertama adalah memberikan pengetahuan terlebih dahulu yang sesuai dengan experiencenya dengan media kalam, tahapan yang kedua adalah mengajak berdialog, tahapan yang ketiga adalah memberi pemahaman dan tahapan yang terakhir adalah memberikan peringatan. Bentuk strategi ini bisa disinkronkan dalam teori komunikasi adalah merupakan strategi komunikasi pull strategi dimana proses komunikasi yang menekaknkan pada keberhasilan meraih khalayak sebanyak mungkin yang tujuannya meningkatkan 
kesadaran dan mengarahkan perilaku. dengan menganalisa nilai-nilai yang ditunjukan yang menciptakan pengertian dalam komunikasi membina dan memotivasi agar dapat mencapai tujuan yang diinginkan komunikator

Pola komunikasi nabi Muhammad dengan Allah memiliki dua pola komunikasi yaitu pola komunikasi langsung dan tidak langsung dan memiliki semua prinsip dalam komunikasi tetapi yang ditekankan dalam strategi komunikasi ini adalah prinsip mempengaruhi dimana menciptakan hubungan yang sehat yang berbentuk pengaruh strategi komunikasi yang dapat merubah pendapat orang menjadi faktor baik dan buruknya manusia

\section{DAFTAR PUSTAKA}

Arni Muhammad, Komunikasi Organisasi ( Jakarta: Bumi aksara 2001)

Hafied Cangara, Pengantar Ilmu Komunikasi ( Jakarta: Pt Raja Grafindo 2002)

Harjani hefni, Komunikasi Islam (Jakarta: Kencana 2003)

https://alquranmulia.wordpress.com/2013/01/05/asbabun-nuzul-surah-al-alaq/

Lidwa Pusaka i-Software - Kitab 9 Imam Hadist Sumber : Bukhari Kitab : Ta'bir Bab : Wahyu pertama-tama No. Hadist : 6467

Muhammad Fuad, Abdul Baqi, Kumpulan Hadist shohih bukhori muslim ( Solo: Insan Kamil 2010)

Phil. Astrid S. Susanto, Komunikasi Massa (bandung: Angkasa offset 1982)

Setiawan Hari Purnomo, Manajemen Strategi : Sebuah Konsep Pengantar, (Jakarta:Fakultas Ekonomi Universitas Indonesia, 1996)

Sondang P Siagian, Filsafah Administrasi, (Jakarta:CV Masaagung, 1990)

Syaiful rohim, Teori-Teori Komunikasi Perspektif Ragam dan Aplikasi (Jakarta:rineka cipta2009)

Tommy suprapto pengantar teori komunikasi (Yogyakarta:madia pressindo2006) 